\title{
GMR
}

\section{Characterization of a pepper collection (Capsicum frutescens L.) from Brazil}

\author{
M.F. Lima ${ }^{1}$, S.I.C. Carvalho ${ }^{1}$, C.F. Ragassi ${ }^{1}$, L.B. Bianchetti ${ }^{2}$, \\ F.G. Faleiro ${ }^{3}$ and F.J.B. Reifschneider ${ }^{4}$ \\ ${ }^{1}$ Embrapa Hortaliças, Brasília, DF, Brasil \\ ${ }^{2}$ Embrapa Recursos Genéticos e Biotecnologia, Brasília, DF, Brasil \\ ${ }^{3}$ Embrapa Cerrados, Brasília, DF, Brasil \\ ${ }^{4}$ Embrapa Secretaria de Relações Internacionais, Brasília, DF, Brasil \\ Corresponding author: M.F. Lima \\ E-mail: mirtes.lima@embrapa.br
}

Genet. Mol. Res. 16 (3): gmr16039704

Received April 17, 2017

Accepted July 21, 2017

Published August 31, 2017

DOI http://dx.doi.org/10.4238/gmr16039704

Copyright (C) 2017 The Authors. This is an open-access article distributed under the terms of the Creative Commons Attribution ShareAlike (CC BY-SA) 4.0 License.

\begin{abstract}
Germplasm banks are essential as sources of genetic variability for plant breeding programs. To characterize a Brazilian Capsicum frutescens collection, 21 malagueta and 5 Tabasco hot pepper accessions were evaluated under field and greenhouse conditions regarding morphological and molecular traits, as well as resistance to viruses. Morphological characterization was performed using 53 IPGRI (International Plant Genetic Resources Institute) descriptors, 15 vegetative, 13 inflorescence, 22 fruit, and 3 seed. Molecular characterization was carried out with 60 polymorphic markers from 29 RAPD primers. The incidence of major viruses infecting Capsicum spp, Tomato spotted wilt virus (TSWV), Groundnut ringspot virus (GRSV), Potato virus Y (PVY), Pepper yellow mosaic virus (PepYMV), Pepper mild mottle virus (PMMoV), and Cucumber mosaic virus (CMV) was evaluated by ELISA. Based on the average genetic distance among genotypes, six groups were defined for the 53 IPGRI descriptors. When considering only 11 quantitative traits (five vegetative and six fruit), six
\end{abstract}

Genetics and Molecular Research 16 (3): gmr16039704 
groups were also determined, and the traits plant canopy width (56.05\%) and days to fruiting $(25.07 \%)$ most explained the genetic diversity among genotypes. Molecular analysis defined five groups of accessions with partial correspondence to the morphological characterization data. The incidence of viruses in field-grown plants varied among genotypes and according to virus species, from 5.6\% (GRSV; CNPH 3286 ) to $100 \%$ (PMMoV; CNPH2871), and indicated some accessions as potential sources of virus resistance. These results demonstrate the genetic variability within the group of 26 hot pepper accessions, as well as virus-resistant genotypes that can be used in breeding programs.

Key words: Morphological descriptors; Molecular characterization; Resistance; Virus

\section{INTRODUCTION}

The Capsicum genus in the family Solanaceae comprises five domesticated species, Capsicum chinense Jacq., C. annuum L., C. frutescens L., C. pubescens R. et P., and C. baccatum L. (IBPGR, 1983; Pickersgill, 1997), and 22 wild species (Bosland, 1994). C. frutescens L. is one of the most known species in the genus, usually Tabasco type. However, solely two morphological types are widely cultivated, the malagueta hot pepper, as it is known in Brazil, from the Amazon Basin, and Tabasco, originated from the Tabasco region of Mexico, grown in the United States since 1840, which is largely used in the production of sauce (Jarret et al., 2007). The Brazilian malagueta is the largest grown and consumed hot pepper type throughout the country, especially in the States of Minas Gerais and São Paulo (Southeast region), the State of Bahia (Northeast region) and the State of Goiás (Midwest region). Moreover, in the State of Ceará (Northeast region), Tabasco is also grown for exporting as a paste for the sauce.

In Brazil, a few records on hot pepper acreages and yield are available, which do not reflect the current economic position occupied by the crop. Hot peppers are primarily grown by small farmers in a total family agriculture system, in several localities of the country. According to Carvalho et al. (2015), about 5000 hectares are annually grown with hot peppers and total fruit production may reach around 75,000 tons. Yield tends to be very variable, records ranging from 5 t/ha (Ribeiro et al., 2008) to 50 t/ha (Ribeiro et al., 2015), depending on many factors, such as the type of hot pepper planted.

Hot peppers are grown by small-, medium-, and large-scale farmers, the cultivation fitting the small farmer models, as an alternative crop considered an important source of income to attend the fresh and the processed markets. However, just a few cultivars reaching good standards of purity and genetic stability are available to growers in the Brazilian market. Furthermore, the majority of growers tend to produce and use their seeds by saving seeds from previous plantings, undergoing low germination rates, because of low seed quality and risk of carrying pathogens (Ribeiro et al., 2008). The development of new malagueta cultivars with desirable characteristics, such as agronomic and processing traits of interest, is highly desirable for improving the hot pepper agribusiness competitiveness in Brazil. Such approach, however, depends on the genetic resources preserved and available in germplasm banks, which is the basis for pepper breeding programs by improving efficiency and crop production. The Capsicum Germplasm Bank of the Brazilian Agricultural Research Corporation (Embrapa)

Genetics and Molecular Research 16 (3): gmr16039704 
started in the 1970's (Reifschneider et al., 2016). Nowadays, it stores over 4,000 domesticated, semi-domesticated, and wild pepper accessions collected from different Brazilian regions, comprising two centers of genetic diversity for Capsicum species (Reifschneider et al., 2009). Accessions of the Embrapa's Germplasm Bank have a wide variability of fruit traits such as color, shape, flavor, the degree of pungency, as well as useful resistance to the major pepper diseases (Ribeiro et al., 2008).

Characterization of the genetic variability found in a germplasm bank is one of the first and the most important steps towards developing a breeding program. The information generated through detailed investigation on crop features including morphologic, molecular, and other traits of interest allows identifying duplicates and selecting genotypes of interest for breeding purposes (Engles and Visser, 2003). To guide this characterization, the Bioversity International, formerly IPGRI (International Plant Genetic Resources Institute), provides a list of morphological descriptors internationally accepted and considered as a standard for economically important crops, including the Capsicum species (http://www. bioversityinternational.org/research/conservation/sharing_information/descriptor_lists.htm).

A combination of plant, flower, and fruit traits was used to characterize the Embrapa's C. frutescens collection and to identify promising and useful hot pepper accessions to be employed in breeding programs. In addition to the morphologic approach, molecular analysis of genotypes was also performed, since it improves characterization accuracy, by providing a complementary map of the genetic variability in a Germplasm Bank and identifying traits of interest.

The use of molecular markers, complementing morphological characterization data, has been a useful approach that helps to access genetic diversity in germplasm collections. However, available data on the genetic diversity of hot pepper by using molecular tools is still quite limited. Molecular techniques such as RAPD (randomly amplified polymorphic DNA), RFLP (restriction fragment length polymorphism), SSRs (simple sequence repeats), AFLP (amplified fragment length polymorphism), and microsatellites have been employed for estimating genetic diversity among and within Capsicum species (Baral and Bosland, 2004; Costa et al., 2009; Moses et al., 2014; Dhaliwal et al., 2014; Buso et al., 2016). The molecular marker RAPD has been used as a simple method able to detect DNA polymorphisms, at relatively low costs (Spooner et al., 2005).

Among the diseases that affect Capsicum spp., viruses are the main constraint to hot pepper production, especially to $C$. frutescens, around the world, including Brazil.

The potyviruses (family Potyviridae, Potyvirus genus) Pepper yellow mosaic virus (PepYMV), and Potato virus Y (PVY), the orthotospoviruses (family Tospoviridae, Orthotospovirus genus) Tomato spotted wilt virus (TSWV), and Groundnut ringspot virus (GRSV), the tobamovirus (family Virgaviridae, Tobamovirus genus) Pepper mild mottle virus (PMMoV), and the cucumovirus (Bromoviridae family, Cucumovirus genus) Cucumber mosaic virus (CMV) are among the most important viruses infecting hot peppers worldwide (Inoue-Nagata et al., 2002; Pernezny et al., 2003; Lima et al., 2011a) and causing yield losses. Furthermore, investigation of sources of resistance to viral diseases in a hot pepper germplasm collection is mandatory for identifying potential genotypes for breeding purposes.

The objective of this study was to characterize a set of 26 genotypes of malagueta and Tabasco hot peppers (C. frutescens) from the Embrapa Germplasm Bank regarding morphological and molecular traits, as well as virus resistance, aiming to the selection of promising accessions for deployment in breeding programs.

Genetics and Molecular Research 16 (3): gmr16039704 


\section{MATERIAL AND METHODS}

\section{Accessions}

Field and in insect-proof greenhouse assays were carried out in the Experimental Station of Embrapa Vegetables, Brasília, DF, Brazil, located at $15^{\circ} 56^{\prime} 32^{\prime \prime} \mathrm{S}$ and $48^{\circ} 08^{\prime} 25^{\prime \prime} \mathrm{W}$, elevation $998 \mathrm{~m}$, in a distroferric red soil. Morphological and molecular characterization, as well as virus incidence, was performed on a set of 21 malagueta and five Tabasco hot pepper (C. frutescens L.) accessions from the Embrapa's Capsicum Germplasm Bank. Seedlings were obtained by pre-germinating seeds in plastic boxes type Gearbox $(11 \times 11 \times 3.5 \mathrm{~cm})$ on moistened filter paper in a $0.2 \% \mathrm{KNO}_{3}(\mathrm{w}: \mathrm{v})$ solution to break dormancy. Then, seeds were maintained at $30^{\circ} \mathrm{C}$ for $8 \mathrm{~h}$ in the absence of light and at $20^{\circ} \mathrm{C}$ for $16 \mathrm{~h}$ under fluorescent light. Eight to ten days later, seedlings were transferred to trays with 72 cells containing a mixture of an organic substrate $\left(\operatorname{Plantimax}^{\mathbb{R}}\right)$ and soil $(1: 1, \mathrm{v} / \mathrm{v})$, and they were maintained in a greenhouse for 30-45 days. Seedlings were transplanted to the field and also in 10-L plastic pots containing sterile soil $\left(120^{\circ} \mathrm{C}\right.$ for $\left.1 \mathrm{~h}\right)$ in a screen house. In the field, $0.60 \mathrm{~m}$ spacing was used between plants and $1.2 \mathrm{~m}$ between rows. Fertilization was carried out according to the standard practices recommended for pepper production systems (Alcântara and Ribeiro, 2008). Sprinkling irrigation was used in the field, and dripping irrigation was used in the screen house.

\section{Morphological characterization}

The evaluation of morphologic traits was performed both in the field and in a screen house. Fifty-three descriptors recommended for Capsicum and established by the IPGRI (1995) were employed including 15 vegetative (seedling traits were disregarded), 13 inflorescence, 22 fruit, and 3 seed. Fruit position, fruit aroma, and first branch height were also measured, totalizing 56 descriptors. All data were collected from five plants per accession and ten fruits per plant. Fresh fruit weight was taken from 20 units per plant. Agronomic traits of interest associated with flower (flower position; the number of flowers per axil), fruit (days to fruiting; the color of mature fruit; fruit weight; fruit length; fruit width), and production were evaluated only in field-grown plants.

Based on averages of morphological traits, coefficients of genetic dissimilarity were estimated for each pair of accessions, according to the average standardized Euclidean distance (Steel and Torrie, 1980). Then, the matrix of genetic dissimilarity was used for cluster analysis based on the unweighted pair-group method arithmetic average (UPGMA). The cophenetic correlation coefficient (r) calculated between the original genetic distance matrix and the distance represented by the dendrogram between pairs of genotypes was used to estimate the adjustments between the dissimilarity matrix and the resulting dendrogram (Sokal and Rohlf, 1962), using the NTSYS pc 2.1 program (Rohlf, 2000).

Dispersion analysis was carried out according to multidimensional scales by the method of main coordinates, based on the genetic distance matrix. Eleven quantitative descriptors were further examined in a separate analysis including five vegetative traits (stem length; stem diameter; plant width; days to flowering; days to fruiting), and six fruit (wall thickness; the number of locules; fruit length; fruit width; fruit weight; fruit peduncle length). Data analysis was carried out with SAS (SAS Institute Inc., 1989) and Statistica (StatSoft Inc.,

Genetics and Molecular Research 16 (3): gmr16039704 
1999). Clustering of the accessions was done with a support of UPGMA analysis. The relative contribution of each quantitative trait to the genetic diversity was determined according to Singh (1981), using the Genes statistical program (Cruz, 2004).

\section{Molecular characterization}

A set of 498 random primers (Operon Technologies, USA) for RAPD were tested against a collection of hot pepper genotypes for selection of oligonucleotides able at generating reproducible and high-intensity polymorphic amplicons among accessions. Primer screening was supported by comparative analysis of molecular patterns produced by six hot pepper accessions (CNPH 2871; CNPH 3649; CNPH 3630; CNPH 3612; CNPH 3374; CNPH 3453) having distinct morphological traits and which were considered as representative of the $C$. frutescens variability in the Germplasm Bank. The group was composed by an accession having a yellow fruit color at maturity (CNPH 2871), a malagueta with excessive pilosity (CNPH 3649), a Tabasco (CNPH 3630), two common malaguetas (CNPH 3374 and CNPH 3612, the latter being highly productive), and a hot pepper with a yellow fruit color when ripe (CNPH 3453). Apical young leaves collected from greenhouse-grown plants were subjected to genomic DNA extraction, by using a modified $2 \mathrm{X}$ CTAB method. Estimative of DNA concentration was carried out using $\lambda$ DNA (Invitrogen, Carlsbad, CA, USA) as standard. The integrity of extracted DNA was checked on $1 \%$ agarose gel electrophoresis stained with ethidium bromide and visualized under ultraviolet light. Amplification reactions were prepared as follow: $1.25 \mu \mathrm{L} 10 \mathrm{X}$ PCR buffer (200 mM Tris-HCl, pH 8.4; $500 \mathrm{mM} \mathrm{KCl);} 0.60 \mu \mathrm{L} 50 \mathrm{mM} \mathrm{MgCl}_{2} ; 0.50 \mu \mathrm{L} 10 \mathrm{mM}$ dNTPs; $2.0 \mu \mathrm{L} 100 \mu \mathrm{M}$ primer; $1 \mathrm{U}$ enzyme Taq DNA Polymerase (Invitrogen); $2.0 \mu \mathrm{L}$ total DNA $(25 \mathrm{ng} / \mu \mathrm{L})$ and, $5.95 \mu \mathrm{L}$ deionized water in a total volume of $12.5 \mu \mathrm{L}$. For testing accuracy and avoiding detection of unstable polymorphisms, samples were analyzed in duplicate. Thus, any generated information with the possibility of raising doubts about the occurrence of polymorphism or its reproducibility was disregarded. PCR amplification was performed in a thermal cycler (GeneAmp PCR System 9700) using the following parameters: $2 \mathrm{~min}$ at $94^{\circ} \mathrm{C}$ followed by 35 cycles of $0.5 \mathrm{~min}$ at $94^{\circ} \mathrm{C}, 1 \mathrm{~min}$ at $36^{\circ} \mathrm{C}$, and a 1.5 -min extension at $72^{\circ} \mathrm{C}$; and a final extension of $10 \mathrm{~min}$ at $68^{\circ} \mathrm{C}$. Amplified PCR products were analyzed for polymorphism detection in a $1.5 \%$ agarose gel electrophoresis, in running buffer $1 \mathrm{X}$ Tris-borate-EDTA (TBE) (0.09 M Tris-borate; 0.002 M EDTA), after ethidium bromide staining $(12.5 \mathrm{ng} / \mathrm{mL})$. Gels were electrophoresed at $100 \mathrm{~V}$ for $2.5 \mathrm{~h}$ and visualized under ultraviolet light.

To generate an array of binary data, presence or absence of RAPD fragments on the gel was scored for each primer as ' 1 ' and ' 0 ', respectively. Molecular similarity (MS) for each pair of accessions was estimated from the RAPD matrix using the Jaccard's algorithm on the Genes software (Cruz, 2004). Dissimilarity coefficients were calculated by subtracting MS from the unit value (1 - MS) and used for dendrogram construction with the UPGMA cluster algorithm. The average dissimilarity between accessions was calculated by the NTSYS-pc software and clustering of genotypes was based on the resulting value (Rohlf, 2000). A vertical dashed line was drawn at this corresponding position in the $\mathrm{x}$-axis to cut the dendrogram and separate accessions into groups. The consistency of clustering was evaluated by 1000 bootstrap simulations using the Genes software.

Genetics and Molecular Research 16 (3): gmr16039704 


\section{Assessment of virus incidence}

Four field trials were conducted at the Experimental Station of Embrapa Vegetables, Brasília, DF, Brazil, to assess virus incidence in 26 hot pepper genotypes. Plantings were established during two consecutive growing seasons (January to August/2009; August to January/2010) by transplanting 30-day-old seedlings produced in the greenhouse. Virus sources in the field consisted of pepper plants naturally infected with viruses and exhibiting typical symptoms of viral infection, confirmed by DAS-ELISA (double-antibody sandwich-enzyme-linked immunosorbent assay; Clark and Adams, 1977) using polyclonal antibodies against each virus.

Virus incidence was evaluated by collecting leaf samples at approximately 60 days after seedling transplant to the field when characteristic and distinct symptoms of viral infection (mosaic; mottling; reduction of leaf size; plant stunting; leaf distortion; chlorotic rings) could be observed in plants.

A total of 307 leaf samples ranging in average from 8 to 18 plants per accession were collected for serological testing. Plants displaying or not displaying typical virus symptoms were individually sampled and subjected to analysis by DAS- ELISA, using specific antisera against orthotospoviruses (TSWV and GRSV), potyviruses (PVY and PepYMV), a tobamovirus (PMMoV), and a cucumovirus (CMV), the most important group of viral agents infecting Capsicum species.

Virus identification was performed in each plant aiming at generating incidence data for each virus species in each accession. An individual sample consisted of shoots and leaves collected from 3-4 different branches of the same plant, to compose a sample considered as representative per plant.

Samples were individually identified in plastic bags and were maintained on ice in Styrofoam boxes, immediately subjected to a serological test or maintained at $4^{\circ} \mathrm{C}$ until processing. Plant extracts were obtained by grinding of leaves in extraction buffer $(1.4 \mathrm{M} \mathrm{NaCl}$; $\left.0.02 \mathrm{M} \mathrm{KH}_{2} \mathrm{PO}_{4} ; 0.08 \mathrm{M} \mathrm{Na}_{2} \mathrm{HPO}_{4} .12 \mathrm{H}_{2} \mathrm{O} ; 0.02 \mathrm{M} \mathrm{KCl} ; \mathrm{pH} 7.4\right)$, in the proportion of 1:10 (w:v; g/mL). Pepper plants (Capsicum annuum L.), cv. Ikeda, mechanically inoculated with each virus or not were used as positive (infected) and negative (healthy) controls, respectively, in the detection tests. Antibodies and conjugates were used at a concentration of $1 \mathrm{mg} / \mathrm{mL}$, and readings of absorbance values were taken at $405 \mathrm{~nm}$ in a plate reader (Titertek Multiskan). In assessing virus incidence, samples were considered as positive and, therefore, infected with the specific virus, when absorbance values of the reading were at least three times higher the mean value recorded for the extract used as negative control. Thus, absorbance values below the standard adopted were considered as an indicator of the absence of infection by viruses (Sutula et al., 1986). The percentage of infected plants with each virus species was classified as follow: $\mathrm{L}=$ low (up to $20 \%$ of infected plants), $\mathrm{M}=$ average (20.1 $-30 \%$ of infected plants), $\mathrm{H}=$ high $(>30 \%$ of infected plants).

\section{RESULTS}

\section{Morphological characterization}

Morphological characterization of C. frutescens accessions using IPGRI (1995) descriptors allowed the identification of genetic variability among the 26 genotypes (Figures 1 and 2) having different geographical origins and diverse characteristics of fruit.

Genetics and Molecular Research 16 (3): gmr16039704 


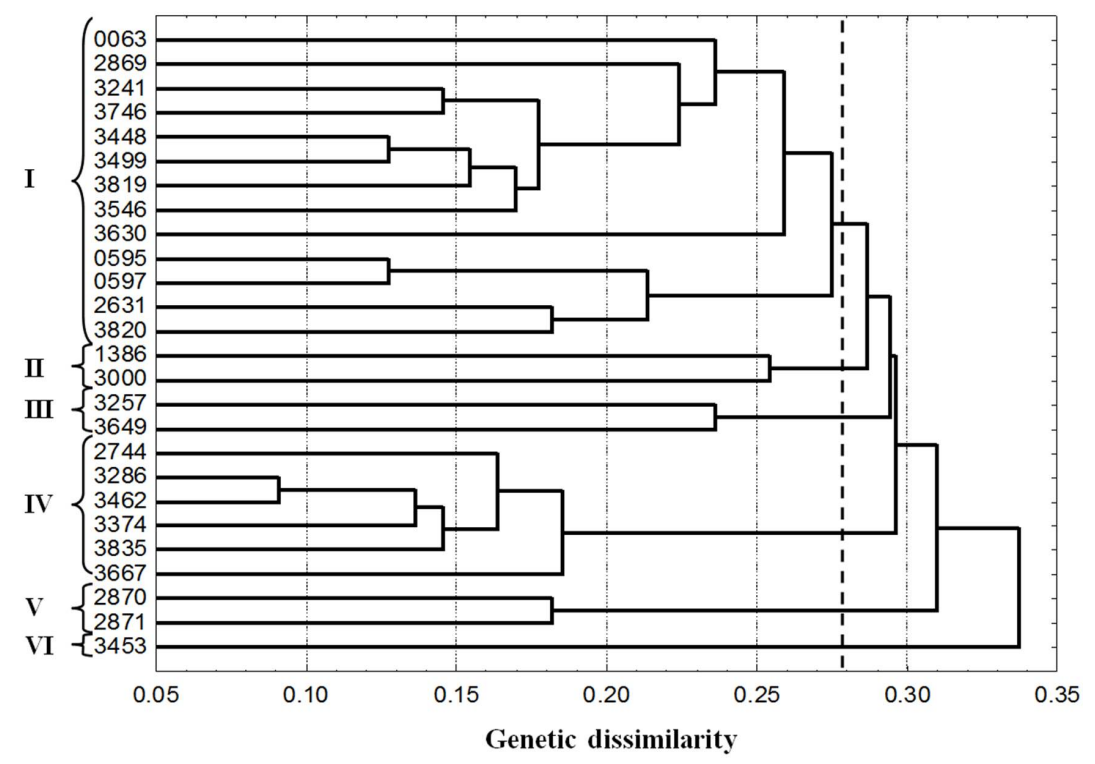

Figure 1. Dendrogram for 26 accessions of malagueta hot pepper (Capsicum frutescens) from the Capsicum Germplasm Bank of Embrapa Vegetables, using 56 morphological descriptors. The dotted line indicates the vertical position of the cutoff value equivalent to the average dissimilarity between accessions $(0.2797)$ for the formation of the six groups indicated by Roman numerals (left).

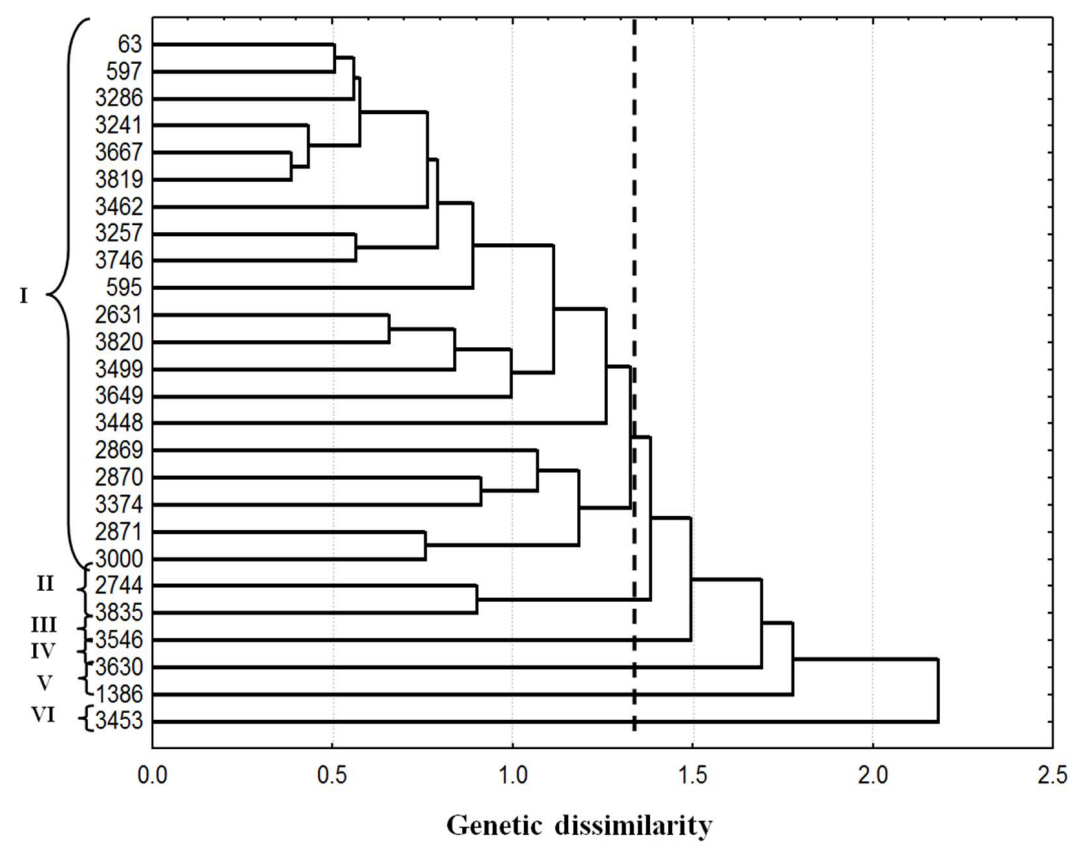

Figure 2. Genetic dissimilarity between 26 accessions of malagueta and Tabasco hot peppers (Capsicum frutescens) using eleven quantitative characters.

Genetics and Molecular Research 16 (3): gmr16039704 
Of 56 descriptors, 15 were monomorphic for all the 26 hot pepper accessions, indicating the absence of genetic variability among genotypes for these traits. From these, at least eight descriptors were absent. The other non-polymorphic traits were as follow: stem pubescence (sparsely), leaf margin (entire), pose flower (erect), corolla color (greenish-white), fruit shape (stretched), seed color (yellow), and seed surface (smooth).

Six major groups of accessions were determined (Figure 1), according to the average dissimilarity values between accessions (0.2797) generated from the genetic dissimilarity matrix data. Group I comprised the majority of accessions (13), Groups II and III comprised two accessions each, Group IV comprised six, and Groups V and VI comprised two and one accessions, respectively.

Group I, the largest one, included diverse genotypes having broad geographical representation in Brazil. About 86.3\% (11) were collected in the five Brazilian regions (North; Northeast; South; Southeast; Midwest) and one in the United States. Data on fruiting were very variable for days to fruiting (from 47 to 135 days); weight ( 0.3 to $1.0 \mathrm{~g}$ ); length (1.5 to $3.2 \mathrm{~cm}$ ); width (0.5 to $1.8 \mathrm{~cm})$, and wall thickness $(0.4$ to $1.2 \mathrm{~mm})$.

Accession CNPH 1386, collected in the Arapiraca County, in the State of Alagoas (AL), and CNPH 3000, from the Asian Vegetable Research Development Center (AVRDC), formed Group II. Both accessions had similar traits regarding vegetative part (growth habit, the density of branching, anthocyanin nodal, foliar density, and pubescence) and fruit (color of the fruit when ripe, the degree of pungency, and fruit aroma). Both genotypes also exhibited distinct fruit characteristics (color when immature; persistence; fruit length and width; wall thickness; fruit weight; pedicel length, and the number of seeds per fruit). Fruits of CNPH 1386 were bigger, had low persistence, were green when immature, and produced 20-50 seeds per fruit; while CNPH 3000 produced smaller fruits of a yellow color when immature, were persistent, and produced less than 20 seeds per fruit.

Group III was formed by two accessions (CNPH 3257 and CNPH 3649) collected respectively in the Northeastern Brazil, at São Luis County, in the State of Maranhão and Teresina County, in the State of Piauí. Accession CNPH 3649 diverged from the other 25 accessions by presenting sparse foliage and branching density, one flower per axil, an intermediate corolla form, and a fruit weight of $1.3 \mathrm{~g}$. Two descriptors (dense leaf pubescence; stigma position) differentiated these two genotypes from the other ones. For both accessions, the stigma position was on the same level as the anthers, differing from the majority of the other genotypes, which showed stigma above the anthers (excerpt).

Group IV consisted of a different cluster of six accessions, originated from Brasília (DF) and different Brazilian locations: Belém and Castanhal, in the State of Pará (PA); Iranduba, in the State of Amazonas (AM); and São Paulo State (SP). The fruit was persistent and red colored when ripe. Variability was verified for canopy width $(90-137 \mathrm{~cm})$, stem length (22-31.8 cm), and stem diameter. Accession CNPH 3835 had the largest stem diameter (2.6 $\mathrm{cm}$ ) among the 26 genotypes. Variability was also found for flowering and fruiting stages: days to flowering from 41 (CNPH 3462) to 74 (CNPH 2744) and the number of flowers per axil from 1-2 (CNPH 2744; CNPH 3667; CNPH 3462) to 2-4 (CNPH 3286; CNPH 3374; CNPH $3835)$. Days to fruiting varied from 70 (CNPH 3462) to 132 (CNPH 3374) and fruits diverged on weight $(0.3$ to $1 \mathrm{~g})$, length $(1.6$ to $2.9 \mathrm{~cm})$, and width $(0.5$ to $1.6 \mathrm{~cm})$.

Two accessions collected at Guajari Mirim and Porto Velho, in the State of Rondônia (RO), in the Northern Brazil formed the Group V. Stem length varied from $25 \mathrm{~cm}$ (CNPH

Genetics and Molecular Research 16 (3): gmr16039704 
$2870)$ to $33 \mathrm{~cm}$ (CNPH 2871), and stem diameter varied from $1.5 \mathrm{~cm}(\mathrm{CNPH} 2870)$ to $1 \mathrm{~cm}$ (CNPH 2871). These accessions also diverged at fruit characteristics such as color at maturity (red and yellow, respectively, for CNPH 2870 and CNPH 2871); fruit length (from $2.5 \mathrm{~cm}$ for CNPH 2870 to $3 \mathrm{~cm}$ for CNPH 2871), fruit width (from $0.5 \mathrm{~cm}$ for CNPH 2870 to $0.8 \mathrm{~cm}$ for $\mathrm{CNPH} 2871$ ), and fruit weight (from $0.4 \mathrm{~g}$ for CNPH 2870 to $0.8 \mathrm{~g}$ for CNPH 2871).

Group VI consisted of solely one accession (CNPH 3453) from Manaus, in the State of Amazonas (AM), Northern Brazil. It was an early accession, presenting 41 days to flowering; however, it produced a small number of flowers per axil, only 1-2. The fruit was persistent, very hot, average flavored, with the largest weight $(1.1 \mathrm{~g})$, the greatest length $(3.9 \mathrm{~cm})$, and one of the thickest wall $(0.9 \mathrm{~mm})$ among all accessions. Besides, it had a pedicel length of 3 $\mathrm{cm}$ and produced up to 20 seeds per fruit. Fruits were green when immature and yellow when ripe. Two unique features recorded for CNPH 3453 were placenta length (from $1 / 4$ to $1 / 2$ of the fruit length), and fruit presenting three locules. All other accessions presented bilocular fruit and placenta length greater than half-length of the fruit.

\section{Quantitative traits}

Analysis of a set comprising eleven quantitative descriptors (stem length; stem diameter; plant width; days to flowering; days to fruiting; fruit wall thickness; number of locules; fruit length; fruit width; fruit weight; fruit pedicel length) defined six distinct groups (Figure 2) similar to the morphological characterization (Figure 1). Group I comprised the majority of accessions (20) and Group II, only two accessions. The other groups had exclusively one accession each. The relative contribution of each quantitative trait determined by Singh's method (1981) indicated that plant canopy width $(90$ to $199 \mathrm{~cm}$ ) and days to fruiting (47 to 155 days) were the most efficient traits to explain the genetic diversity among accessions, 56.05 and $25.07 \%$, respectively. Days to flowering (47 to 155 days) and stem length (22 to $62 \mathrm{~cm}$ ) accounted for 13.28 and $5.55 \%$ of the genetic variability, respectively. Inputs from each of the other seven remaining characters were not significant, less than $1 \%$. Comparison between both morphological analyses, in one hand the analysis held in the full set of 56 traits (Figure 1) and, on the other hand, the analysis considering 11 quantitative descriptors (Figure 2), showed partial match of accession clustering, higher than $57 \%$ (15 accessions). These data indicate the importance of quantitative traits in the definition of groups. Group I of both analyses gathered 11 accessions in common (Figures 1 and 2). The accessions CNPH 2744 and CNPH 3835, which formed the Group II (Figure 2), also stood together in the same group in the analysis with 56 characters (Group IV; Figure 1). However, CNPH 1386 and CNPH 3453 clustered in distinct groups for both analyses (Figures 1 and 2). While CNPH 1386 assembled with CNPH 3000 in Group II (Figure 1), CNPH 3453 formed a group of a single accession in both cases (Group VI; Figures 1 and 2), indicating that it diverged from the other genotypes. Only CNPH 3546 (Group III) and CNPH 3630 (Group IV) were clustered into two groups each accession (Figure 2).

Based on multidimensional scaling by principal coordinate analysis, a large group comprising 19 accessions was formed, according to the scatter plot of accessions (Figure 3). These data mostly agreed $(84.21 \%)$ with results shown by the dendrogram in Figure 2, and 16 accessions were assembled to form Group I (Figures 2 and 3). Considering the other seven accessions, three of them, CNPH 3546, CNPH 3453, and CNPH 1386, formed isolated groups (Figure 2), Group III, Group IV, and Group V, respectively.

Genetics and Molecular Research 16 (3): gmr16039704 


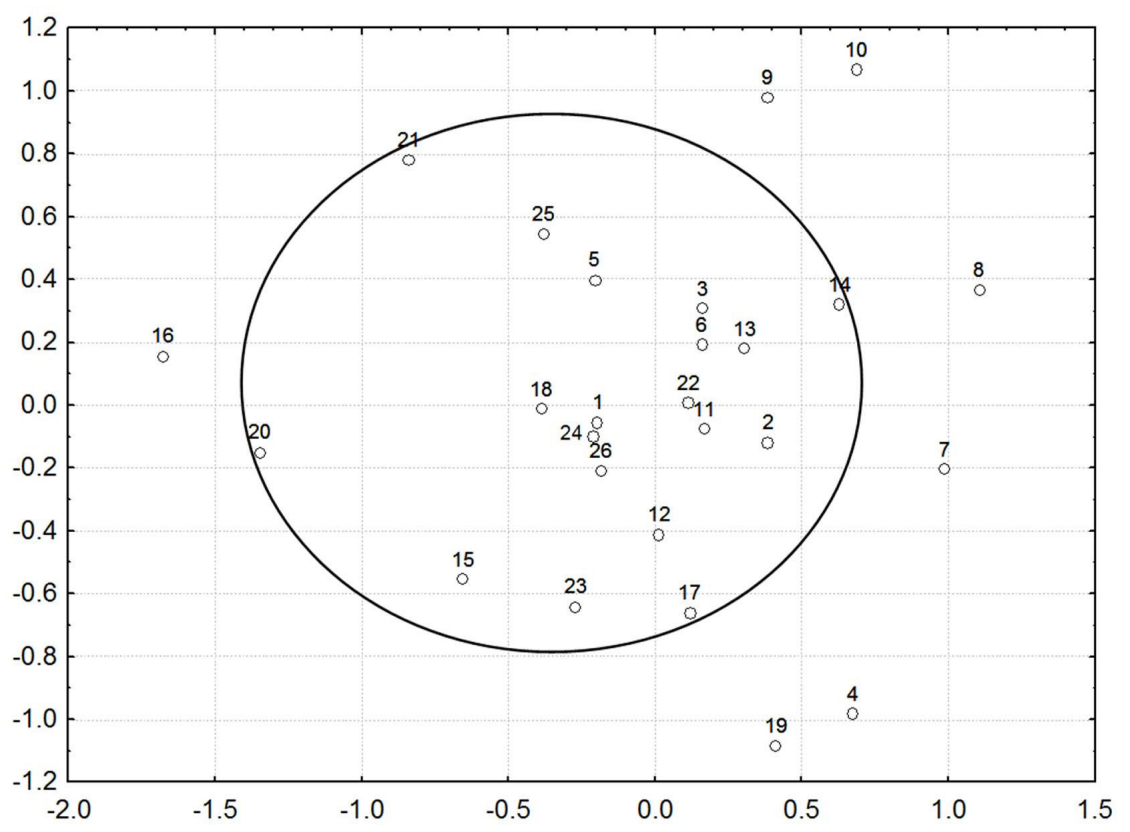

Figure 3. Scatter plot of 26 accessions of malagueta and Tabasco hot peppers (Capsicum frutescens) based on genetic distance matrix for eleven quantitative characters. $(1=\mathrm{CNPH} 0063 ; 2=\mathrm{CNPH} 595 ; 3=\mathrm{CNPH} 597 ; 4=$ $\mathrm{CNPH} 1386 ; 5=\mathrm{CNPH} 2631 ; 6=\mathrm{CNPH} 2744 ; 7=\mathrm{CNPH} 2869 ; 8=\mathrm{CNPH} 2870 ; 9=\mathrm{CNPH} 2871 ; 10=\mathrm{CNPH}$ $3000 ; 11=\mathrm{CNPH} 3241 ; 12=\mathrm{CNPH} 3257 ; 13=\mathrm{CNPH} 3286 ; 14=\mathrm{CNPH} 3374 ; 15=\mathrm{CNPH} 3448 ; 16=\mathrm{CNPH}$ $3453 ; 17=\mathrm{CNPH} 3462 ; 18=\mathrm{CNPH} 3499 ; 19=\mathrm{CNPH} 3546 ; 20=\mathrm{CNPH} 3630 ; 21=\mathrm{CNPH} 3649 ; 22=\mathrm{CNPH}$ $3667 ; 23=\mathrm{CNPH} 3746 ; 24=\mathrm{CNPH} 3819 ; 25=\mathrm{CNPH} 3820 ; 26=\mathrm{CNPH} 3835)$.

\section{Molecular characterization}

Eighty $(16.1 \%)$ primers were selected from the PCR-RAPD-based screening and 29 (5.8\%; OPA07, OPA020, OPD05, OPD11, OPQ04, OPQ11, OPS10, OPX03, OPA04, OPA08, OPA15, OPA17, OPA19, OPB08, OPC10, OPG05, OPG07, OPG11, OPH02, OPH11, OPQ11, OPX03, OPK17, OPM09, OPO02, OPO07, OPQ07, OPQ08, and OPR17) confirmed polymorphism presence among the 26 accessions, in two replicates. The 29-primer set yielded 254 amplicons, of which 194 (76.4\%) were monomorphic and 60 (23.6\%) polymorphic. Amplicon average per primer was $8.7 \mathrm{bp}$. However, the number of amplicons per primer varied from 7 (OPA20; OPA15; OPG11; OPH02; OPH11, and OPX03) to 14 (OPG05), amplifying DNA-fragments between $3000 \mathrm{bp}$ (OPH11) and $300 \mathrm{bp}$ (OPM9). The dendrogram of dissimilarity among all the accessions (Figure 4) was generated based on 60 polymorphic markers. A vertical line was traced on the x-axis, in a position corresponding to the average value of dissimilarity between accessions (0.315), generating five clusters of accessions.

The first group was composed of typical malagueta accessions (Figure 4). These accessions have as common traits upright growth habit, pubescent leaves and sparse stems, whitish-green and upright flower; cup of fruit without basal constriction; bilocular fruit, elongated and upright fruit position, fruit green when immature and red at maturity, fruit wall thickness $<1 \mathrm{~mm}$ and low persistence (high ease of detachment when ripe; except CNPH 0595 that produced fruits with intermediate persistence).

Genetics and Molecular Research 16 (3): gmr16039704 


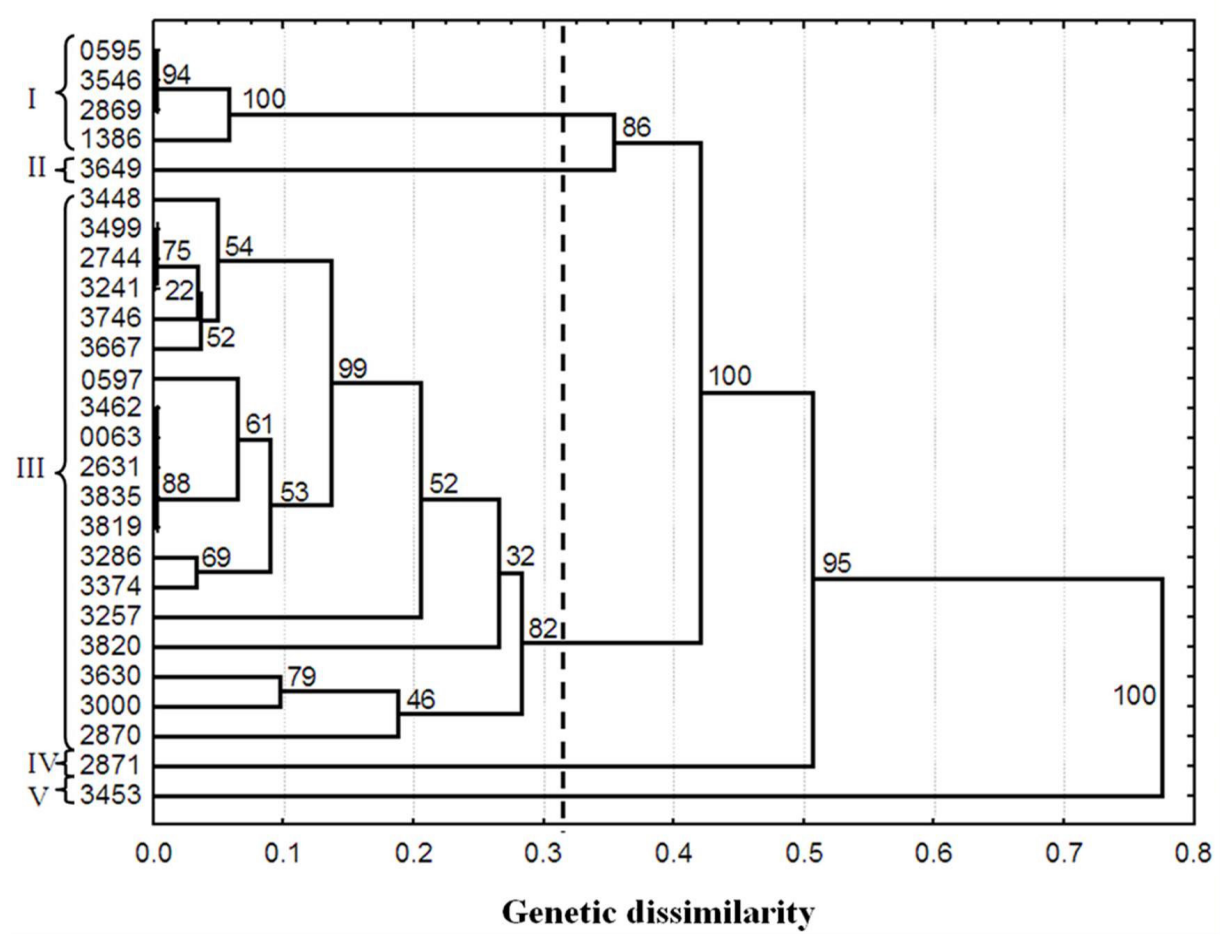

Figure 4. Genetic dissimilarity among 26 accessions in the Brazilian Germplasm Bank of Capsicum frutescens of Embrapa Vegetables. The numbers located above the bifurcation correspond to their reliability indexes calculated by the bootstrap method, and the Roman numerals indicate the groups established by the court in an amount equivalent to the average dissimilarity between accessions $(0.315)$.

The second group consisted of only CNPH 3649. Despite having characteristics similar to the malagueta morphotype, CNPH 3649 has excessive leaf pilosity and the highest fruit weight recorded among all the accessions $(1.3 \mathrm{~g})$. Furthermore, it was the only accession with sparse branching density and sparse leaf density, one flower per axil and intermediate corolla, then, differing from the other accessions.

The third and largest group was formed by 19 genotypes (Figure 4), in which intermediate growth habit was predominant, except for CNPH 3000, CNPH 3257, and CNPH 3820, which presented erect growth habit. Accessions CNPH 3667, CNPH 3630, CNPH 3257, CNPH 3000, and CNPH 2870, characterized as Tabasco morphotype, clustered in the third group.

The fourth and fifth groups were formed by CNPH 2871 and CNPH 3453, respectively. Morphologically distinct from the majority accessions, CNPH 2871 produced fruits of yellow color even when ripe, and plant shorter in height, between 66 and $85 \mathrm{~cm}$. According to both morphological (Figure 1) and molecular (Figure 4) clustering data, CNPH 2871 is a type of $C$. frutescens; however, with different characteristics.

Accessions of Tabasco morphotype (CNPH 3667, CNPH 3630, CNPH 3257, CNPH 3000 , and CNPH 2870) presented fruit coloration varying from green to orange during the ripening process. A cluster of groups based on average dissimilarity among accessions had bootstrap coefficient values (Figure 4) equal to or higher than $86 \%$, indicating the high

Genetics and Molecular Research 16 (3): gmr16039704 
reliability of clustering analysis. Furthermore, the CNPH 2871 and CNPH 3453, considered the most divergent in the studied collection, were separated from other accessions with 95 and $100 \%$ bootstrap coefficients (Figure 4), respectively; reinforcing the reliability of the results.

\section{Assessment of virus incidence}

Hot pepper plants of different accessions exhibited variable incidence of virus symptoms in the field. This variation occurred according to the level of resistance of each hot pepper accession to each virus species, stage of plant development at the time of infection, virus species infecting plants of each accession, infection of the same plant by different virus species, among other factors. Symptom development occurred as a green or yellow mosaic, mottling, and vein banding on leaves and leaf deformation with a reduced size. Additionally, chlorotic and necrotic rings were observed on leaves and fruits. Infected plants were stunted and exhibited a sharp reduction in plant development when compared with non-infected hot pepper plants. Symptom severity was more pronounced in plants that were infected at early stages of development or when more than one viral species were found in the same plant in common multiple virus infections. The occurrence of mixed infection makes it difficult evaluating symptoms induced by a single virus species in plants and, therefore, to make any association between field symptoms and results obtained in the serological tests.

Symptoms of viral diseases were observed about 2-3 weeks after seedling transplanting to the field, indicating that infection of plants has occurred early at seedling stage. Moreover, it also indicated that the proximity to inocula sources of viruses, represented by older Capsicum spp fields infected with viruses and infested with insect vectors, favored the occurrence of viral infection in hot pepper plants of different accessions.

The incidence of viruses for the 26 hot pepper accessions was calculated according to serological test results (Table 1).

From a total of 307 plants, $53.4 \%$ (164 samples) were virus-infected in single or mixed infection, indicating the importance of viral pathogens to hot pepper crop. A total of $46.6 \%$ had no infection caused by PVY, PepYMV, TSWV, GRSV, CMV, or PMMoV.

The percentage of virus-infected plants ranged between 12.1\% (37 samples) for PVY and $32.6 \%$ (100) to PMMoV. The other virus species, TSWV, PepYMV, and GRSV, occurred in $59(17.3 \%), 52(15.2 \%)$, and $45(13.2 \%)$ plants, respectively. No CMV-infected plant was found.

Infection by orthotospoviruses ranged from 5.6\% (TSWV and GRSV: CNPH 3286) to $58.3 \%$ (TSWV: CNPH 0063); however, in seven accessions, these viruses were not found (Table 1). TSWV was the most common orthotospovirus species infecting hot pepper plants; for nine accessions, the incidence of TSWV was considered high $(>30 \%)$, for six, average ( 20.1 to $30 \%$ ) and, for nine, low (up to $20 \%$ of infected plants). Serological results for GRSV were similar, with four accessions with high infection rate, six in average, and ten low.

The potyviruses (PVY; PepYMV) were detected in $35 \%$ of the plants. Virus incidence ranged from 6.7\% (PVY: CNPH 3667) to 58.3\% (PepYMV: CNPH 2631). These results indicate the importance of both viruses, especially PepYMV, to hot pepper crop. The percentage of PepYMV-infected plants was considered as high for five accessions, the average for one, and as low for twelve accessions. PVY incidence was classified as high (four accessions), as average (four), and low (seven). Plants of eight and eleven accessions, respectively, were not infected with PepYMV and PVY. However, for both viruses, no infection was detected in the accessions CNPH 0597, CNPH 3241, CNPH 3499, and CNPH 3819.

Genetics and Molecular Research 16 (3): gmr16039704 
Table 1. Incidence of orthotospoviruses (Tomato spotted wilt virus - TSWV; Groundnut ringspot virus - GRSV), potyviruses (Pepper yellow mosaic virus - PepYMV; Potato virus Y - PVY), and Pepper mild mottle virus (PMMoV) in a collection of 26 malagueta and Tabasco hot peppers (Capsicum frutescens) using polyclonal antibodies by DAS-ELISA (double-antibody sandwich-enzyme-linked immunosorbent assay) (Brasília, DF, Brazil - Embrapa Vegetables).

\begin{tabular}{|c|c|c|c|c|c|c|c|c|c|c|c|c|}
\hline Accession & Origin & Sample (N) & & & $\begin{array}{c}\mathrm{GR} \\
(\%\end{array}$ & & $\begin{array}{r}\text { Pep } \\
(\%)\end{array}$ & & $\begin{array}{l}\mathrm{PV} \\
(\%\end{array}$ & & & \\
\hline CNPH 0063 & Minas Gerais & 12 & 58.3 & $\mathrm{H}$ & 8.3 & $\mathrm{~L}$ & 33.3 & $\mathrm{H}$ & 8.3 & $\mathrm{~L}$ & 58.3 & $\mathrm{H}$ \\
\hline CNPH 0595 & Sete Lagoas, MG & 12 & 0 & $\mathrm{nd}^{/ 2}$ & 25 & $\mathrm{M}$ & 16.7 & $\mathrm{~L}$ & 0 & nd & 41.7 & $\mathrm{H}$ \\
\hline CNPH 0597 & Anápolis, GO & 9 & 33.3 & $\mathrm{H}$ & 0 & nd & 0 & nd & 0 & nd & 0 & nd \\
\hline CNPH 1386 & Arapiraca, AL & 13 & 30.8 & $\mathrm{H}$ & 15.4 & $\mathrm{~L}$ & 15.4 & $\mathrm{~L}$ & 30.8 & $\mathrm{M}$ & 53.8 & $\mathrm{H}$ \\
\hline CNPH 2631 & Paracatu, MG & 12 & 25 & $\mathrm{M}$ & 33.3 & $\mathrm{H}$ & 58.3 & $\mathrm{H}$ & 8.3 & $\mathrm{~L}$ & 8.3 & $\mathrm{~L}$ \\
\hline CNPH 2744 & Belém, PA & 13 & 46.2 & $\mathrm{H}$ & 0 & nd & 7.7 & $\mathrm{~L}$ & 23.1 & $\mathrm{M}$ & 61.5 & $\mathrm{H}$ \\
\hline CNPH 2869 & Guajari Mirim, RO & 11 & 18.2 & $\mathrm{~L}$ & 18.2 & $\mathrm{~L}$ & 18.2 & $\mathrm{~L}$ & 36.4 & $\mathrm{H}$ & 27.3 & $\mathrm{M}$ \\
\hline CNPH 2870 & Guajari Mirim, RO & 12 & 50 & $\mathrm{H}$ & 16.7 & $\mathrm{~L}$ & 58.3 & $\mathrm{H}$ & 50 & $\mathrm{H}$ & 58.3 & $\mathrm{H}$ \\
\hline CNPH 2871 & Porto Velho, RO & 8 & 50 & $\mathrm{H}$ & 50 & $\mathrm{H}$ & 0 & nd & 37.5 & $\mathrm{H}$ & 100 & $\mathrm{H}$ \\
\hline CNPH 3000 & AVRDC & 9 & 0 & nd & 11.1 & $\mathrm{~L}$ & 22.2 & $\mathrm{M}$ & 22.2 & $\mathrm{M}$ & 33.3 & $\mathrm{H}$ \\
\hline CNPH 3241 & Brasília, DF & 13 & 0 & nd & 0 & nd & 0 & nd & 0 & nd & 15.4 & $\mathrm{~L}$ \\
\hline CNPH 3257 & São Luis, MA & 13 & 7.7 & $\mathrm{~L}$ & 23.1 & $\mathrm{M}$ & 7.7 & $\mathrm{~L}$ & 0 & nd & 53.8 & $\mathrm{H}$ \\
\hline CNPH 3374 & Brasília, DF & 12 & 33.3 & $\mathrm{H}$ & 25 & $\mathrm{M}$ & 0 & nd & 8.3 & $\mathrm{~L}$ & 50 & $\mathrm{H}$ \\
\hline CNPH 3286 & Castanhal, PA & 18 & 5.6 & $\mathrm{~L}$ & 5.6 & $\mathrm{~L}$ & 16.7 & $\mathrm{~L}$ & 0 & nd & 44.4 & $\mathrm{H}$ \\
\hline CNPH 3453 & Manaus, AM & 11 & 0 & nd & 9.1 & $\mathrm{~L}$ & 9.1 & $\mathrm{~L}$ & 27.3 & $\mathrm{M}$ & 18.2 & $\mathrm{~L}$ \\
\hline CNPH 3448 & Manaus, AM & 13 & 53.8 & $\mathrm{H}$ & 23.1 & $\mathrm{M}$ & 15.4 & $\mathrm{~L}$ & 0 & nd & 38.5 & $\mathrm{H}$ \\
\hline CNPH 3462 & Iranduba, AM & 12 & 8.3 & $\mathrm{~L}$ & 25 & $\mathrm{M}$ & 41.7 & $\mathrm{H}$ & 0 & nd & 8.3 & $\mathrm{~L}$ \\
\hline CNPH 3499 & Manacapuru, AM & 12 & 8.3 & $\mathrm{~L}$ & 0 & nd & 0 & nd & 0 & nd & 0 & nd \\
\hline CNPH 3546 & Itacoatira, AM & 12 & 41.7 & $\mathrm{H}$ & 40 & $\mathrm{H}$ & 16.7 & $\mathrm{~L}$ & 41.6 & $\mathrm{H}$ & 50 & $\mathrm{H}$ \\
\hline CNPH 3630 & USA & 12 & 0 & $\mathrm{Nd}$ & 16.7 & $\mathrm{~L}$ & 8.3 & $\mathrm{~L}$ & 8.3 & $\mathrm{~L}$ & 25 & $\mathrm{H}$ \\
\hline CNPH 3649 & Teresina, PI & 5 & 0 & $\mathrm{Nd}$ & 0 & nd & 20 & $\mathrm{~L}$ & 0 & nd & 0 & nd \\
\hline CNPH 3667 & ISLA & 15 & 6.7 & $\mathrm{~L}$ & 13.3 & $\mathrm{~B}$ & 0 & nd & 6.7 & $\mathrm{~L}$ & 6.7 & $\mathrm{~L}$ \\
\hline CNPH 3746 & Curitiba, PR & 10 & 10 & $\mathrm{~L}$ & 0 & nd & 20 & $\mathrm{~L}$ & 0 & nd & 50 & $\mathrm{H}$ \\
\hline CNPH 3819 & AGROCERES & 13 & 7.7 & $\mathrm{~L}$ & 0 & nd & 0 & nd & 0 & nd & 30.8 & $\mathrm{H}$ \\
\hline CNPH 3820 & Salvador, BA & 12 & 8.3 & $\mathrm{~L}$ & 8.3 & $\mathrm{~L}$ & 53.8 & $\mathrm{H}$ & 8.3 & $\mathrm{~L}$ & 0 & nd \\
\hline CNPH 3835 & TOPSEED & 13 & 0 & $\mathrm{Nd}$ & 38.5 & $\mathrm{H}$ & 0 & nd & 7.7 & $\mathrm{~L}$ & 15.4 & $\mathrm{H}$ \\
\hline Total & - & 307 & - & - & - & - & - & - & - & - & - & - \\
\hline
\end{tabular}

${ }^{\prime I} \mathrm{I}=$ virus incidence: $\mathrm{L}=$ low $(\leq 20 \%$ of plants infected $) ; \mathrm{M}=$ medium $(20.1-30 \%$ of plants infected $) ; \mathrm{H}=$ high $\left(>30 \%\right.$ of plants infected); ${ }^{12}$ nd: not detected.

PMMoV infection was verified in plants of $61.5 \%$ of the 26 accessions, with an incidence ranging from $6.7 \%(\mathrm{CNPH} 3746)$ to $100 \%(\mathrm{CNPH} 2871)$. However, for four accessions (CNPH 0597; CNPH 3499; CNPH 3649; CNPH 3820) no PMMoV-infected plants were detected. For only CNPH 2869, the PMMoV incidence was considered as average, and in five accessions (CNPH 2631; CNPH 3241; CNPH 3453; CNPH 3462; CNPH 3667) it was low. PMMoV is a highly important virus considering its nature of being naturally seed and mechanically transmitted in the field, as well.

Considering the other analyses performed on the 26 accessions, CNPH 3241, CNPH 3746, CNPH 3819, CNPH 3630, CNPH 3667, and CNPH 3286 that gathered together into a single group for the molecular analysis (Group III; Figure 4) were also in the same group of accession considered as susceptible to PMMoV. However, these genotypes were classified into distinct groups (Groups I and IV) on morphological descriptors (Figure 1). The accession CNPH 2871 was highly susceptible to TSWV (50\%), GRSV (50\%), PVY (37.5\%), and PMMoV (100\%); however, no PepYMV-infected plants were identified for this genotype.

Distinct morphological characteristics and low virus incidence were observed for CNPH 3649 originating from Northeastern Brazil. It clustered together with CNPH 3257, in Group III for morphological traits (Figure 1) and formed a separate group (Group II) in the molecular analysis (Figure 4). This divergent access, CNPH 3649, also had unique 
morphological features such as sparse density of foliage and branching, just one flower per axil, an intermediate corolla form, and large fruit $(1.3 \mathrm{~g})$.

The accessions CNPH 3499 and CNPH 3649 are important to be highlighted because of lower incidence of viral diseases in the field. CNPH 3499 also had a greater wall thickness $(1.2 \mathrm{~mm})$, which makes it a promising source of pulp. Furthermore, it was grouped with several other genotypes regarding the morphological descriptors (Group I) and the molecular characterization (Group II) (Figures 1 and 4). CNPH 3241, CNPH 3746, CNPH 3819, CNPH 3630, CNPH 3667, and CNPH 3286 also presented reduced number of virus-infected plants; however, the incidence of PMMoV estimated by serological tests in plants of these genotypes varied from low for both the first accessions to high for the others (Table 1).

\section{DISCUSSION}

In a hot pepper breeding program, it should be considered a group of morphoagronomical characteristics of the working collection, fruit quality, market requirements, and preferences, as well as different forms of pepper consumption: fresh, bottled sauces, or liquids (Ribeiro et al., 2008). For fresh market, malagueta fruits with larger size and weight are preferred and CNPH 3649 (fruit length $=3.5 \mathrm{~cm}$, width $=1 \mathrm{~cm}$, weight $=1.3 \mathrm{~g}$, wall thickness $=1 \mathrm{~mm}$ ) and CNPH 3453 (fruit length $=3.9 \mathrm{~cm}$, width $=0.8 \mathrm{~cm}$, weight $=1.1$ $\mathrm{g}$, wall thickness $=0.9 \mathrm{~mm}$ ) meet these requirements. However, if they are for processing, fruits must be adapted to filling or small and preferably fruit to be easily detachable from the cup (low persistence), and that result in no wounds to prevent browning after packaging. Accessions CNPH 0595, CNPH 1386, CNPH 2869, CNPH 2870, CNPH 2871, CNPH 3546, and CNPH 3630 meet the requirements for being processed. Also, CNPH 3630 was the earliest (39 days to flowering) among all accessions and produced the greatest number of flowers (3-5 per axil), considered as an important feature for breeding programs since it favors the attainment of higher yields.

Despite having small fruits, malagueta and Tabasco pepper types are used in the manufacture of liquid sauces, eaten raw, or mixed with other hot pepper types in the preparation of spicy sauces (Ribeiro et al., 2008). Then, fruit with greater wall thickness provides higher amounts of pulp such as CNPH $3499(1.2 \mathrm{~mm})$, CNPH $3630(1.0 \mathrm{~mm})$, CNPH $3649(1.0 \mathrm{~mm})$, and CNPH $3820(1.0 \mathrm{~mm})$, which attend this niche market.

All accessions characterized in the present study showed uniform characteristics and no segregation was detected in plant or fruit, as well. The main fruit characteristics displayed were: small, elongated shape, usually red color when ripe, very thin wall thickness, and high concentration of capsaicin (the alkaloid that gives chili burning). These data are in agreement with DeWitt and Bosland (2009) and indicate low morphological variability within C. frutescens species, especially regarding fruit shape and color, when compared to other domesticated hot pepper species of the same genus. From our results, five Tabasco accessions (CNPH 3667, CNPH 3630, CNPH 3257, CNPH 3000, and CNPH 2870) differed from the other accessions by presenting distinct fruit color change throughout the ripening process. While for Tabasco type, fruit color varied from pale green, pale yellow, orange, and red from immature to mature stages, for the common malagueta, a color change occurs from green to red during the ripening process. However, despite having this remarkable difference on a specific fruit trait, it was not expected that Tabasco type cluster in diverse groups, aside from the common malaguetas, as shown by morphological and molecular characterization results (Figures 1,

Genetics and Molecular Research 16 (3): gmr16039704 
2, and 4). Considering that Tabasco is the only $C$. frutescens considered to be domesticated (Pickersgill, 1971) and that Tabasco genotypes have been grouped indistinctly with malagueta on morphological and molecular analyses presented herein, results demonstrate the high genetic similarity between these two groups, and suggest that Tabasco may have been selected and domesticated from wild populations of malagueta.

Some accessions of $C$. chinense can be confused with $C$. frutescens due to close genetic similarity. The main morphological distinction between these species is the presence of the annular constriction, located between the calyx and peduncle, found only in fruits of C. chinense (Carvalho et al., 2014). In the present study, this trait was not identified for all accessions, confirming their identification as C. frutescens.

A different morphological type observed in this study was CNPH 2871, which showed a yellow fruit when ripe and, thus, distinct from the other accessions studied in both morphological and molecular characterization. DeWitt and Bosland (2009) described $C$. frutescens accessions having the fruit of yellow color; however, only when immature, all of them presenting red color when ripe. Furthermore, for at least five descriptors, CNPH 2871 showed different results from all other genotypes studied: length of the plant between 66 and $85 \mathrm{~cm}$, pose of fruit intermediate, the color of stem streaked with green, yellow fruit when ripe, and a cross-section of the fruit intermediate. The origin of CNPH 2871 in Porto Velho, Rondônia State, reinforces this distinction since the Amazon Basin is the main center of $C$. chinense and $C$. frutescens diversity (Barbosa et al., 2010).

Positioning CNPH 2871 (yellow when ripe) and CNPH 3649 (hairy leaves), which showed unique characteristics in relation to the collection studied, also indicates the presence of correlation between morphological evaluation carried out based on qualitative data and molecular analysis, since in both analyses, these genotypes were separated from the larger groups, consisting predominantly of the common hot peppers. Accession CNPH 2871 also presented virus incidence of $37.5,50$, and $100 \%$, respectively, for PVY, TSWV, and GRSV and, PMMoV. However, no PepYMV-infected plants were detected; this is an interesting result, considering that PepYMV, described by Inoue-Nagata et al. (2002), became an important virus to Capsicum spp in Brazil and had been detected in most of the pepper-producing regions of the country. Thus, the search for sources of resistance to PepYMV has been carried out aiming to identify promising genotypes to be used in breeding programs. The resistance to PepYMV in hot pepper has been reported in the cultivar BRS Mari (C. baccatum) launched by Embrapa Vegetables (Carvalho et al., 2009).

A comparison of the groups set based on molecular analysis with those resulting from morphological characterization indicated the consistency of the results. For all methodologies used, accession CNPH 3453 was the most divergent within the germplasm collection evaluated. It produces pale-orange fruits and, based on its morphological characteristics in comparison to the characterization of $C$. chinense (Finger et al., 2010; Baba et al., 2016) such accession may belong to the $C$. chinense species and had been mistakenly allocated in the $C$. frutescens bank. In the three cluster analysis, CNPH 3453 formed a separate group (Figures 1, 2, and 4). It is worth to point out that the CNPH 3453 genotype could not be accurately classified as $C$. frutescens solely according to morphological traits.

For most of the plants tested, virus infection was detected with variable incidence among different accessions. Failure to detect these types of viruses in the tested plants indicates that, although some plants were symptomatic, these plants were not infected with TSWV, GRSV, TCSV, PVY, PepYMV, CMV, and PMMoV or these viruses might be present

Genetics and Molecular Research 16 (3): gmr16039704 
in low concentration in plants. In this case, the title would be below the detection threshold of the technique. Another hypothesis is that the symptoms could have been induced by different virus species from those previously mentioned. The positive control reacted as expected with high values of absorbance, and the values for the positive samples were at least twice more than those of the negative control, indicating that the ELISA was performed correctly. The results also indicate that the antisera used in the evaluations were efficient in detecting these viruses consistently and specifically in the evaluated plants.

The reaction of pepper accessions to natural infection with orthotospoviruses (TSWV; GRSV), potyviruses (PVY; PepYMV), tobamovirus (PMMoV), and cucumovirus (CMV) in the field was quite variable, revealing different levels of resistance of the hot pepper accessions to the different species of viruses (Table 1). The predominance of PMMoV among the detected viruses (Lima et al., 2011b) reaffirms its high efficiency of transmission through seeds and during cultivation. The available methods for treatment of PMMoV-infected seeds use heat and trisodium phosphate trying to remove the virus and controlling seed transmission (Jarret et al., 2008). Among the plants that tested positive for PMMoV, many of them may have been infected in the field during the crop management practices, indicating the importance of mechanical transmission of PMMoV from plants originated from infected seeds, which is the primary virus inoculum, to healthy plants. According to Lewandowski (1999), PMMoV is transmitted between plants by mechanical contact with sources contaminated with the virus and through the soil and seeds. The importance of PMMoV to the hot pepper crop and its detection in most accessions tested indicate the need for developing effective and efficient strategies for disease management. In addition to its placement in contaminated seed, it must also be considered the simple mechanical transmission of the virus, the high stability of viral particles that can be easily spread in the field through the hands of workers, and contact between plants. This virus can be easily spread in the crop and cause significant economic losses.

All these results reveal the correspondence between the data generated herein from the study of 26 C. frutescens accessions by using different approaches, morphological descriptors, molecular characterization, and reaction to viruses. Besides, these data reaffirm the importance of the viral diseases to the hot pepper cultivation, which is the major constraint to C. frutescens production, in Brazil (Lima et al. 2011a). Thus, identification of sources of resistance to these pathogens to be used in breeding programs for incorporation into commercial cultivars having favorable agronomic characteristics is highly desirable.

Phenotypic and genotypic variability was observed between the C. frutescens accessions evaluated herein, as well as the occurrence of a short distance between the morphological and molecular characterization data generated. The information generated by the characterization of 26 different accessions, especially those related to fruit, is essential to the progress of the Capsicum breeding program of Embrapa Vegetables. The evaluation of malagueta and Tabasco hot pepper accessions in a Germplasm Bank is necessary and important to generate information on genetic variability to serve as a support to the development of crop management strategies, as well as to the Capsicum breeding program.

\section{ACKNOWLEDGMENTS}

The authors thank Conselho Nacional de Desenvolvimento Científico e Tecnológico $(\mathrm{CNPq})$ for partial funding of the project and for granting research scholarship to F.J.B. Reifschneider.

Genetics and Molecular Research 16 (3): gmr16039704 


\section{REFERENCES}

Alcântara FA and Ribeiro CSC (2008). Solos e Adubação. In: Pimentas Capsicum (Ribeiro CSC, Lopes CA, Carvalho SIC, Henz GP, et al., eds.). Embrapa Hortaliças, Brasília, 81-93.

Baba VY, Rocha KR, Gomes GP, Ruas CF, et al. (2016). Genetic diversity of Capsicum chinense accessions based on fruit morphological characterization and AFLP markers. Genet. Resour. Crop Evol. 63: 1371-1381. https://doi. org $/ 10.1007 / \mathrm{s} 10722-015-0325-4$

Baral JB and Bosland PW (2004). Unraveling the species dilemma in Capsicum frutescens and C. chinense (Solanaceae): a multiple evidence approach using morphology, molecular analysis, and sexual compatibility. J. Am. Soc. Hortic. Sci. 129: 826-832.

Barbosa RI, Mourão Júnior M and Luz FJF (2010). Morphometric patterns and preferential uses of Capsicum peppers in the state of Roraima, Brazilian Amazonia. Hortic. Bras. 28: 477-482. https://doi.org/10.1590/S0102$\underline{05362010000400017}$

Bosland PW (1994). Chiles: history, cultivation, and uses. In: Spices, herbs, and edible fungi (Charalambous G, ed.). Elsevier Publishers, New York, 347-366.

Buso GSC, Reis AMM, Amaral ZPS and Ferreira ME (2016). Novel and highly informative Capsicum SSR markers and their cross-species transferability. Genet. Mol. Res. 15:gmr.15038689.

Carvalho SIC, Ribeiro CSC, Henz GP and Reifschneider FJB (2009). 'BRS Mari': new hot pepper cultivar for processing. Hortic. Bras. 27: 571-573. https://doi.org/10.1590/S0102-05362009000400028

Carvalho SIC, Ragassi CF, Bianchetti LB, Reifschneider FJB, et al. (2014). Morphological and genetic relationships between wild and domesticated forms of peppers (Capsicum frutescens L. and C. chinense Jacquin). Genet. Mol. Res. 13: 7447-7464. https://doi.org/10.4238/2014.September.12.11

Carvalho SIC, Ragassi CF, Oliveira IB, Amaral ZPS, et al. (2015). Transferability of microsatellite markers of Capsicum annuum L. to C. frutescens L. and C. chinense Jacq. Genet. Mol. Res. 14: 7937-7946. https://doi.org/10.4238/2015. July.17.1

Clark MF and Adams AN (1977). Characteristics of the microplate method of enzyme-linked immunosorbent assay for the detection of plant viruses. J. Gen. Virol. 34: 475-483. https://doi.org/10.1099/0022-1317-34-3-475

Costa FR, Pereira TNS, Sudré CP and Rodrigues R (2009). Marcadores RAPD e caracteres morfoagronômicos na determinação da diversidade genética entre acessos de pimentas e pimentões. Cienc. Rural 39: 696-704. https://doi. org/10.1590/S0103-84782008005000099

Cruz CD (2004). Programa Genes (versão Windows): aplicativo computacional em genética e estatística. $1^{\mathrm{a}}$ ed. UFV, Viçosa.

DeWitt D and Bosland PW (2009). The complete chile pepper book: a gardner's guide to choosing, growing, preserving, and cooking. 1st edn. Timber Press, London.

Dhaliwal MS, Yadav A and Jindal SK (2014). Molecular characterization and diversity analysis in chilli pepper using simple sequence repeats (SSR) markers. Afr. J. Biotechnol. 13: 3137-3143. https://doi.org/10.5897/AJB2014.13695

Engles JMM and Visser B (2003). Genebank management: procedures. In: A guide to effective management of germoplasm collections (Engles JMM and Visser B, eds.). IPGRI, Rome, 60-79.

Finger FL, Lannes SD, Schuelter AR, Doege J, et al. (2010). Genetic diversity of Capsicum chinensis (Solanaceae) accessions based on molecular markers and morphological and agronomic traits. Genet. Mol. Res. 9: 1852-1864. https://doi.org/10.4238/vol9-3gmr891

IBPGR (1983). Genetic resources of Capsicum - a global plan of action. International Board for Plant Genetic Resources. IBPGR Secretariat, Rome.

IPGRI (1995). Descriptors for Capsicum (Capsicum spp.). IPGRI, Rome.

Inoue-Nagata AK, Fonseca MEN, Resende RO, Boiteux LS, et al. (2002). Pepper yellow mosaic virus, a new potyvirus in sweetpepper, Capsicum annuum. Arch. Virol. 147: 849-855. https://doi.org/10.1007/s007050200032

Jarret RL, Baldwin E, Perkins B, Bushway R, et al. (2007). Diversity of fruit quality characteristics in Capsicum frutescens. HortScience 42: 16-19.

Jarret RL, Gillaspie AG, Barkely NA and Pinnow DL (2008). The occurrence and control of pepper mild mottle virus (PMMoV) in the USDA/ARS Capsicum germplasm collection. Seed Technol. 30: 26-36.

Lewandowski DJ (1999). Genus Tobamovirus. In: Virus taxonomy: Taxonomy of Viruses (Van Regenmortel MHV, Fauquet CM, Bishop DHL, Carstens EB, et al., eds.). Academic Press, San Diego, 889-894.

Lima MF, Inoue-Nagata AK, Reifschneider FJB, Ferraz RM, et al. (2011a). Virus Incidence in Domesticated and SemiDomesticated Field-Grown Hot Peppers (Capsicum spp.). Acta Hortic. 917: 285-297. https://doi.org/10.17660/ ActaHortic.2011.917.40

Genetics and Molecular Research 16 (3): gmr16039704 
Lima MF, Inoue-Nagata AK, Reifschneider FJB, Souza KRR, et al. (2011b). Detection, occurrence and natural incidence of Pepper mild mottle virus (PMMoV) in hot peppers in Brazil. Acta Hortic. 917: 269-273. https://doi.org/10.17660/ ActaHortic.2011.917.37

Moses M, Umaharan P and Dayanandan S (2014). Microsatellite based analysis of the genetic structure and diversity of Capsicum chinense in the Neotropics. Genet. Resour. Crop Evol. 61: 741-755. https://doi.org/10.1007/s10722-013$\underline{0069-\mathrm{y}}$

Pernezny K, Roberts PD, Murphy JF and Goldberg NP (2003). Compendium of pepper diseases. 2nd edn. APS Press, St. Paul.

Pickersgill B (1971). Relationships between weedy and cultivated forms in some species of chili peppers (Genus Capsicum). Evolution 25: 683-691.

Pickersgill B (1997). Genetic resources and breeding of Capsicum spp. Euphytica 96: 129-133. https://doi. org/10.1023/A:1002913228101

Reifschneider FJB, Henz GP and Ribeiro CSC (2009). Brazilian Capsicums: Early History and Future Prospects. Chron. Hortic. 33: 9-21.

Reifschneider FJB, Lopes CA and Ribeiro CSC (2016). Continuity, focus and impact: a commented historical perspective on Embrapa Vegetables' extended Capsicum breeding program. Hortic. Bras. 34: 155-160. https://doi.org/10.1590/ $\underline{\mathrm{S} 0102-053620160000200002}$

Ribeiro CS, Lopes CA, Carvalho SIC, Henz GP, et al. (2008). Pimentas Capsicum. 1st edn. Embrapa Hortaliças, Brasília.

Ribeiro CSC, Souza KRR, Carvalho SIC and Reifschneider FJB (2015). BRS Juruti: the first Brazilian habanero-type hot pepper cultivar. Hortic. Bras. 33: 527-529. https://doi.org/10.1590/S0102-053620150000400020

Rohlf FJ (2000). NTSYS-pc: numerical taxonomy and multivariate analysis system, version 2.1. Exeter Software, New York.

SAS Institute Inc (1989). SAS/STAT User's guide. 4th edn. SAS Institute Inc., Cary.

Singh D (1981). The relative importance of characters affecting genetic diversity. Indian J. Genet. Plant Breed. 41: 237245.

Sokal RR and Rohlf FJ (1962). The comparison of dendrograms by objective methods. Taxon 11: 30-40. https://doi. org $/ 10.2307 / 1217208$

Spooner DM, Van Treuren R and de Vicente MC (2005). Molecular markers for genebank management. IPIGRI Technical Bulletin No. 10, International Plant Genetic Resources Institute (IPGRI), Rome.

StatSoft Inc (1999). Statistic for Windows [Computer program manual]. 1st edn. StatSoft Inc., Tulsa.

Steel RGD and Torrie JH (1980). Principles and procedures of statistics a biometrical approach. 2nd edn. McGraw-Hill Publishing, New York.

Sutula CL, Gillet JM, Morrissey SM and Ramsdell DC (1986). Interpreting ELISA data and establishing the positivenegative threshold. Plant Dis. 70: 722-726. https://doi.org/10.1094/PD-70-722

Genetics and Molecular Research 16 (3): gmr16039704 